\title{
Enhancement of Colonisation of Soybean Roots by Arbuscular Mycorrhizal Fungi Using Vermicompost and Biochar
}

\author{
Njunge Leah Wathira*, Wachira Peter, Okoth Sheila \\ School of Biological Sciences, University of Nairobi, Nairobi, Kenya \\ Email address: \\ leahwathira@gmail.com (N. L. Wathira),pwachira@uonbi.ac.ke (W. Peter), dorisokoth@yahoo.com (O. Sheila) \\ *Corresponding author
}

\section{To cite this article:}

Njunge Leah Wathira, Wachira Peter, Okoth Sheila. Enhancement of Colonisation of Soybean Roots by Arbuscular Mycorrhizal Fungi Using Vermicompost and Biochar. Agriculture, Forestry and Fisheries. Vol. 5, No. 3, 2016, pp. 71-78. doi: 10.11648/j.aff.20160503.17

Received: June 6, 2016; Accepted: June 16, 2016; Published: June 30, 2016

\begin{abstract}
Pollution and contamination of soil is one of the major concerns in the world today. Excessive use of synthetic fertilisers has caused tremendous harm to the environment and the human population indirectly. Chemical residues accumulated in crops that find their way to into the human food chain have been found to have adverse health effects. Enrichment of lakes with runoff from heavily-fertilised farms has resulted in eutrophication and pollution of water bodies. Application of organic matter and use of mycorrhiza have been recommended as ways of mitigating these problems. The aim of the study was to investigate the effect of organic amendments on colonisation of soybean roots by arbuscular mycorrhizal fungi. The study consisted of a field experiment of seven treatments with 3 replications in a complete randomized block design. The treatments were biochar $(\mathrm{B})$, vermicompost $(\mathrm{V})$, mycorrhiza $(\mathrm{M})$, biochar and vermicompost (BV), biochar and mycorrhiza (BM), biochar, vermicompost and mycorrhiza (BVM), mycorrhiza and vermicompost (MV), and the control block which had no amendments (NT). Before planting of soybeans and application of amendments, soil samples were collected for characterization of soil chemical properties and mycorrhizal spores. Soybean seeds were planted in each plot. At flowering time, roots were screened for percentage mycorrhizal colonisation and dry mass of plants from each plot was taken. At harvest time, soil samples, plants and harvested soybeans from each plot were collected and dry weight taken. There was mean increase of $53.38 \%$ in levels of phosphorous and $15.33 \%$ of carbon in the soil after application of amendments. Levels of nitrogen decreased in all treatment blocks. There was a significant $(\mathrm{P}<0.0000)$ increase in arbuscular mycorrhizal fungi spores after application of treatments. The colonization percentage of arbuscules in roots was highest (14.7\%) in the bio char and vermicomposting blocks (BV) while the blocks without any treatment, NT, had the lowest colonization percentage of $1.2 \%$. The highest dry weight of both shoots and roots were recorded in blocks treated with biochar which also had the highest weight of harvested soy bean seeds with a mean of $171.28 \mathrm{~g}$. Blocks treated with mycorrhiza had the lowest harvest weight of soybean seeds with a mean of $58.17 \mathrm{~g}$. From this study it was concluded that the organic amendments enhanced the activity of the already-present mycorrhizal fungi in the soil, without requiring the introduction of commercial mycorrhizal amendments and biochar enhances microbial activity which stimulates crop productivity.
\end{abstract}

Keywords: Arbuscular Mycorrhizal Fungi, Organic Amendments, Soybean, Vermicompost, Biochar

\section{Introduction}

Particularly high levels of elements found in synthetic fertilisers like sodium and potassium have been reported to lead to soil and water pollution and loss of biodiversity in soils [1]. One of the most essential macronutrients for plant growth is phosphorous. Phosphorous availability in the soil leads to improvement in leaf area, root growth, stalk and stem vigour, crop maturity and yield; and resistance to pests and diseases. Phosphorous also plays a major role in important processes like photosynthesis, energy transfer and storage, cell enlargement and cell division [2]. Despite its 
presence in soil in organic form, and its addition by farmers in inorganic form, it still remains a limiting nutrient. This is because phosphorous becomes tightly bound with calcium, aluminium or iron, leaching to its precipitation. This causes phosphorous depleted zones to form near the contact areas of roots and soil. Negative effects of inorganic fertilisers and the increased call for sustainable agriculture have led to use of alternative sources of soil amendments to improve the soil [3]. Examples are use of arbuscular mycorrhizal fungi, which assist the plant to take up unavailable nutrients, especially phosphorous; and organic soil amendments like vermicompost and biochar, which improve the quality of the soil.

According to [2], mycorrhiza is a symbiotic association essential for both partners, between a soil fungus and a root of a vascular plant, which is primarily responsible for nutrient transfer. The most well-known associations are arbuscular mycorrhizal (AM) fungi. These derive their name from the tree-like structures they form within root cells of the host plant called arbuscules or hyphal coils. Some species of AM fungi also produce storage organs called vesicles and are called vesicular arbuscular mycorrhizal fungi (VAM fungi) [2]. AM fungi form symbiotic relationships with majority of terrestrial plants. Benefits attributed to this relationship include enhanced uptake of unavailable nutrients, especially phosphorous, higher resistance to disease and improved drought tolerance. These advantages make use of AM fungi attractive for use in sustainable agriculture [4], especially since it could reduce the amount of mineral fertiliser required by growing plants [5]. This would reduce the damage caused to the soil by heavy use of mineral fertilisers. Organic soil amendments have been proposed as alternatives to synthetic fertilisers for the improvement of soil quality. Biological soil amendments have been found to enhance plant nutrient uptake by improving soil physical and chemical properties [5]. Biochar is a porous, fine grained substance with a similar appearance to charcoal produced by slow combustion of biomass under oxygen-limited conditions for the purpose of using it as a soil amendment. Biochar components are decomposed much more slowly than other organic matter in the soil (between 100-1000 years). Because of this, biochar has been suggested for use as a possible carbon sink, because carbon input into soil is more than carbon output through soil microbial respiration [6]. Although biochar has little plant nutrient content, its high surface area and porous structure increase the soil surface area, provide a habitat for beneficial soil microorganisms, aids in water retention and reduces leaching out of nutrients. All of these functions increase availability of nutrients to plants [7].

Vermicompost is a humus-like substance formed when organic matter is broken down by the joint action of earthworms and microorganisms [8]. It is different from compost, which is a product formed from the aerobic decomposition of organic waste like animal droppings, crop wastes and even municipal wastes [9]. Vermicomposts are highly porous, well aerated, well drained and have good water holding capacity. They also contain important nutrients like nitrogen, phosphorous and potassium. Increased biomass and plant height has been attributed to these properties of vermicomposts [10].

Vermicomposts and composts have different physical and chemical properties, and hence different effects on plant growth. This is due to differences in how they are produced [8]. Vermicomposts require less production time than composts. They are also finer in structure and retain nutrients for a longer time. In addition, unlike composts which are more abundant in ammonium, vermicomposts contain high amounts of nitrates, which are a more readily available form of nitrogen. Vermicomposts also have a more abundant supply of important nutrients like potassium and phosphorous and provide a more diverse microbial community than ordinary composts [9]. These properties of vermicompost give it an edge over ordinary composts.

The purpose of this study was to establish whether addition of different types of organic amendments- biochar and vermicompost- to improve soil quality enhances colonisation of soybean roots by AM fungi.

\section{Materials and Methods}

\subsection{Study Area}

The field experimnets were conducted in Naivasha, Kenya, located about $1700 \mathrm{~m}$ above sea level. Average annual rainfall occurs in bimodal peaks from March-May and OctoberDecember and is about $1100 \mathrm{~mm}$. Maximum temperatures are about $25^{\circ} \mathrm{C}$ in the dry season in January and February (www.icipe.org). The area has seven major landscape units: lacustrine plain, volcanic plain, highland, high plateau, low plateau, step-faulted plateau \& volcanic lava-flow plateau. The study area (Sulmac farm) falls under the lacustrine plain. The area has almost flat to gently undulating topography, deep soils, dark olive brown to olive brown, loamy sand to loam, and weak to very weak subangular blocky structure. The dominant soil types include Eutric Cambisols, AreniVitric Andosols, Pach-Sodic Phaeozems, Calcic Cambisols and Cheomic Cambisols. The sandy nature of the topsoil in the area affects the water and nutrient holding capacity of the soils [11].

\subsection{Study Design}

The field treatment consisted of seven treatments used as soil amendments, in plots on which soybean was cultivated. The combinations were as follows: Biochar (B), Vermicompost (V), Mycorrhiza (M), Biochar+Mycorrhiza (BM), Vermicompost+Mycorrhiza (MV), Biochar+Vermicompost+Mycorrhiza (BVM), and control or no treatment (NT). All the treatments were arranged in a complete randomised block design with three replicates.

Land measuring $40 \mathrm{~m}$ by $12 \mathrm{~m}$ was cleared and sub- divided into 24 sub-plots each measuring $3 \mathrm{~m}$ by $2 \mathrm{~m}$. The sub-plots were separated by paths measuring $1 \mathrm{~m}$ wide. Soil samples 
weighing $500 \mathrm{~g}$ were collected using a soil auger, from a depth of $0-20 \mathrm{~cm}$. Samples were collected from different random spots in each experimental block. It was assumed that the soil properties before planting were homogenous, so the samples from the different places were pooled together to make a representative sample. Biochar was applied to the individual holes intended for the seeds and mixed with the soil. It was applied at the rate of $6.75 \mathrm{~kg}$ per plot or $11.25 \mathrm{t} / \mathrm{ha}$, in plots which require biochar alone (B), Biochar+mycorrhiza (BM), biochar, mycorrhiza and vermicompost (BVM) and biochar and vermicompost (BV).

Mycorrhizal treatment applied was Rhizatech ${ }^{(\mathrm{R})}$ supplied by Dudutech Ltd., at the rate of 2.251 per plot or $46.8751 /$ ha. The treatment was applied to the hole before the sowing the seed in plots requiring mycorrhiza alone $(\mathrm{M})$, biochar and mycorrhiza (BM), vermicompost and mycorrhiza (MV) and biochar, vermicompost and mycorrhiza (BVM). Vermicompost treatment used was Vermitech ${ }^{(\mathrm{R})}$ also provided by Dudutech Ltd., mixed with the seed at the time of sowing at the rate of $6.75 \mathrm{~kg}$ per plot of $11.25 \mathrm{t} / \mathrm{ha}$ in the plot requiring vermicompost alone (V), vermicompost and mycorrhiza (MV), vermicompost and biochar (BV) and all three treatments: biochar, vermicompost and mycorrhiza (BVM). Soybean seeds were planted in each treatment plot at the rate of 90 seeds per plot, with a spacing of $30 \mathrm{~cm}$ in between the rows. The field was maintained under irrigation.

\subsection{Data Collection}

At flowering time, ten soybean plants in each plot were randomly selected and carefully uprooted so as to obtain the roots. Roots were cut off from the shoot with some of the surrounding soil, wrapped in damp paper and sealed in labelled polythene bags. These were analysed for root colonisation. At harvest time, soybean pods were harvested and weighed and spread out to dry. After one week, the soybean seeds were extracted from the dry pods and weighed.

\subsection{Samples Preparation}

\subsubsection{Spore Extraction}

The soils were pre-soaked before processing, then mixed with water, stirred and decanted through 710 and 45 micron sieves. This process was repeated several times, and any lumps present were broken between washes. The sediment from the 45 micron sieve was sieved into two or four $50 \mathrm{ml}$ centrifuge tubes, which were balanced by weight and centrifuged for 5 minutes at $1750 \mathrm{rpm}$. Water from the tubes was decanted out and floating debris discarded as well. $48 \%$ sucrose was added to the pellet in the tube, and the substance mixed thoroughly and balanced by weight, before centrifuging for 15 seconds at $1750 \mathrm{rpm}$. The sucrose solution was carefully decanted through a small 45 micron sieve. Spores retained on the sieve were rinsed thoroughly with water to wash out the sucrose. The spores were transferred into a small Petri dish for examination using a dissecting microscope.

\subsubsection{Soil Analysis}

Soil samples collected were analysed for total carbon, nitrogen, $\mathrm{pH}$ and available phosphorous at soil laboratories at Kenya Agricultural Research Institute (KARI). Organic carbon was determined calorimetrically after $\mathrm{H}_{2} \mathrm{SO}_{4}$ dichromate oxidation at $1500 \mathrm{C}$ for 30 minutes. Total Nitrogen was determined by Kieldahl digestion with sulphuric acid and selenium as a catalyst and was estimated calorimetrically. Soil $\mathrm{pH}$ was measured in acqueous suspension (1:2.5 w:v), while phosphorous was extracted with $0.5 \mathrm{M} \mathrm{NaHCO} 3+0.01 \mathrm{M}$ ethylenediaminetetraacetic acid (EDTA) $\mathrm{pH} 8.5$ modified Olsen using a 1:10 soil/solution ratio [12].

\subsubsection{Root Staining}

Root samples were transferred to modified syringes. The root samples were cleared by autoclaving in $2.5 \%$ potassium hydroxide $(\mathrm{KOH})$ for 15 minutes, and then rinsed in water. Bleaching in alkaline hydrogen peroxide was then carried out, after which the roots were again rinsed in water. The root samples were then acidified in $1 \%$ hydrochloric acid (HCL) for one hour, and subsequently stained in $0.05 \%$ trypan blue in acidic glycerol by autoclaving for 3 minutes and finally washed out into a Petri dish for assessment. The roots were cut into pieces approximately $5 \mathrm{~mm}$ in length. Drops of glycerol were placed on a slide, and fifteen root fragments were laid out, one on each drop. Another slide was placed on top of the previous one to protect the root fragments. The fragments were then scored under a compound microscope for extent of root colonisation.

The method described by [13] was used to score occurrence of mycorrhiza in the soybean roots. Three parameters are observed in this method: Frequency of mycorrhiza in root system (F \%), Intensity of Mycorrhizal colonization in root system (M \%), and arbuscule abundance in root system $(\mathrm{A} \%)$.

\subsection{Data Analysis}

After fulfilling the assumption of normality and homogeneity of variances, the data was subjected to analysis of variance (ANOVA) to test the differences in AM colonisation and spore populations. Mean separation was done by Fisher's least significant difference (LSD) at the 0.05 level of probability. The analysis was carried out using Genstat software [12].

\section{Results}

\subsection{Characterisation of the Study Area}

At the beginning of the experiment, soil phosphorous content was $159 \mathrm{ppm}$. The soil $\mathrm{pH}$ level was at 7.38, while nitrogen content was $0.51 \%$. Organic carbon content of the soil before application of treatments was recorded at $0.84 \%$ (Table 1). 
Table 1. Soil, vermicompost and biochar chemical characteristics before the experiment.

\begin{tabular}{llllll}
\hline & PH & $\mathbf{N}(\%)$ & $\mathbf{C}(\%)$ & $\mathbf{K}(\mathbf{C m o l} / \mathbf{k g})$ & $\mathbf{P}(\mathbf{P p m})$ \\
\hline Sample description & & & & & \\
Soil & 7.38 & 0.51 & 0.84 & 1.95 & 159 \\
Vermicompost & 8.5 & 1.54 & 13.18 & 40 & 1130 \\
Biochar & 9.15 & 1.33 & 6.58 & 2 & 50 \\
\hline
\end{tabular}

A total of 2390 isolates were characterized as arbuscular mycorrhizal fungi (AMF) in this study. They were grouped into four genera and ten species. Scutellospora was the most diverse genus with a total of four species, followed by Glomus with a total of three species, with Acaulospora and Gigaspora having one species each. The most frequent species was Glomus etunicatum with a mean occurrence of 23.09, followed by Glomus mosseae and Glomus intraradices, with a mean occurrence of 17.74 and 17.03 respectively in that decreasing order (Table 2).

Table 2. Frequency of arbuscular mycorrhizal fungi isolated before the study.

\begin{tabular}{llllll}
\hline Isolate & Rank & $\begin{array}{l}\text { No. of } \\
\text { isolates }\end{array}$ & Mean & Percentage & $\begin{array}{l}\text { Cum. } \\
\text { frequency }\end{array}$ \\
\hline G. etunicatum & 1 & 531 & 23.09 & 22.2 & 2.7 \\
G. mosseae & 2 & 408 & 17.74 & 17.1 & 2.6 \\
G. intraradices & 3 & 398 & 17.03 & 16.7 & 2.6 \\
S. nigra & 4 & 292 & 12.70 & 12.2 & 2.5 \\
S. verrucosa & 5 & 274 & 11.91 & 11.5 & 2.4 \\
A. denticulata & 6 & 250 & 10.87 & 10.5 & 2.4 \\
S. calospora & 7 & 123 & 5.35 & 5.1 & 2.1 \\
G. albida & 8 & 73 & 3.17 & 3.1 & 1.9 \\
S. pellusida & 9 & 41 & 1.78 & 1.7 & 1.6 \\
\hline
\end{tabular}

\subsection{Effect of Soil Amendments on Soil Chemical Characteristics}

The phosphorous content in the soil increased after addition of soil amendments. The block treated with vermicompost recorded the highest phosphorous content at $262 \mathrm{mg} / \mathrm{kg}$ (Table 3).

Table 3. Soil chemical characteristics before and after application of amendments.

\begin{tabular}{lllll}
\hline \multicolumn{5}{c}{ Soil Chemical Characteristics } \\
\hline & $\mathbf{P}(\mathbf{M g} / \mathbf{K g})$ & $\mathbf{p H}$ & $\mathbf{\% N}$ & $\mathbf{\% C}$ \\
\hline Before treatments & 159 & 7.38 & 0.51 & 0.84 \\
After treatments & $\mathrm{P}(\mathrm{Mg} / \mathrm{Kg})$ & $\mathrm{pH}$ & $\% \mathrm{~N}$ & $\mathbf{0} \mathrm{C}$ \\
M & 215 & 7.17 & 0.112 & 0.86 \\
B & 250 & 7.46 & 0.098 & 0.9 \\
MV & 247 & 7.36 & 0.14 & 0.95 \\
BV & 243 & 7.41 & 0.1 & 1.03 \\
BVM & 250 & 7.4 & 0.112 & 1.08 \\
NT & 245 & 7 & 0.098 & 0.99 \\
BM & 236 & 7.28 & 0.112 & 0.91 \\
V & 262 & 7.36 & 0.098 & 1.03 \\
\hline
\end{tabular}

This was a $64.78 \%$ increase from the initial content, as shown in table 4 . This was followed by the BVM block and the B block, with an increase of $57.23 \%$ (Table 4). The M block recorded the lowest phosphorous content at $215 \mathrm{mg} / \mathrm{kg}$ (Table 3). This was still $37.11 \%$ higher than the initial soil phosphorous content (Table 4).
Table 4. Percentage change in soil chemical characteristics after application of amendments.

\begin{tabular}{lllll}
\hline \multicolumn{5}{c}{ eristics } \\
Treatment & $\mathbf{P}(\mathbf{M g} / \mathbf{K g})$ & $\mathbf{p H}$ & $\mathbf{\%} \mathbf{N}$ & $\mathbf{\% C}$ \\
\hline B & 57.23 & 1.08 & -80.78 & 7.14 \\
BV & 52.83 & 0.41 & -80.39 & 22.62 \\
BVM & 57.23 & 0.27 & -78.04 & 28.57 \\
V & 64.78 & -0.27 & -80.78 & 22.62 \\
MV & 55.34 & -0.27 & -72.55 & 13.1 \\
BM & 48.43 & -1.36 & -78.04 & 8.33 \\
M & 37.11 & -2.85 & -78.04 & 2.38 \\
NT & 54.09 & -5.15 & -80.78 & 17.86 \\
\hline
\end{tabular}

The soil $\mathrm{pH}$ at the end of the experiment increased in some treatment blocks and reduced in others. The biochar block recorded the highest $\mathrm{pH}$ of 7.46 (Table 3), an increase of $1.08 \%$ from the initial $\mathrm{pH}$, followed by that of the BV block with an increase of $0.41 \%$ and BVM with an increase of $0.27 \%$ in that decreasing order (Table 4 ). The mycorrhiza block and the control block recorded the lowest $\mathrm{pH}$ of 7.17 and 7 respectively, as shown in table 3 .

Percentage nitrogen content in the soil decreased after application of amendments, with the highest nitrogen content being recorded in the MV treatment block at $0.14 \%$ (Table 3 ). This was a $72.54 \%$ drop from the initial nitrogen in the soil, as shown in table 4 . The lowest percentage nitrogen was recorded in the $\mathrm{V}, \mathrm{B}$ and control blocks, at $0.098 \%$ which was an $80.78 \%$ drop from initial percentage nitrogen (Tables 3 and 4).

Carbon content in the soil increased as a result of application of amendments. The BVM block recorded the highest carbon content of 1.08 (Table 3 ). This was $28.22 \%$ higher than the initial carbon content in the soil, followed by both $\mathrm{BV}$ and $\mathrm{V}$ blocks, both of which recorded a $22.62 \%$ increase (Table 4). The lowest carbon content of 0.86 was recorded in the mycorrhiza block (Table 3). This was a $2.38 \%$ increase above the initial carbon content (Table 4).

\subsection{Effect of Soil Amendments on Mycorrhizal Spores}

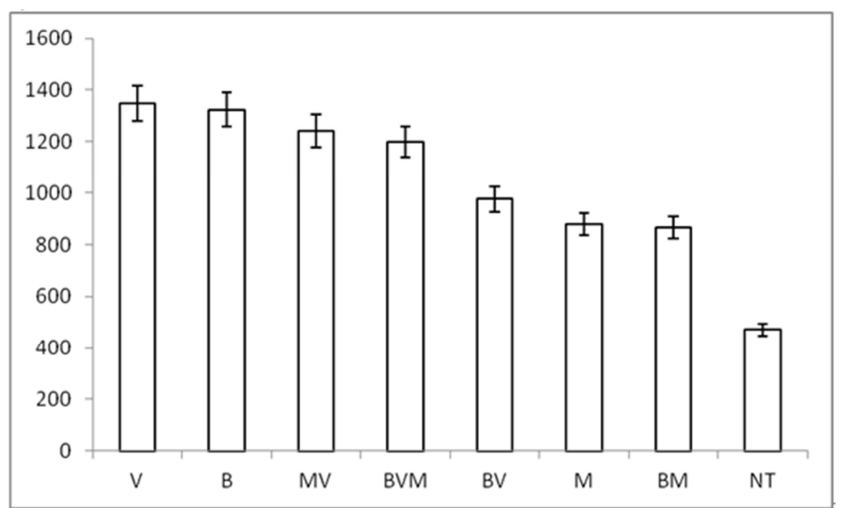

Figure 1. Total occurence of Arbuscular Mycorrhizal fungi across different soil amendments applied.

Key: Vermicompost (V), Biochar (B), Mycorrhiza+Vermicompost (MV), Biochar+Mycorrhiza+Vermicompost (BVM), Biochar+Vermicompost (BV), Mycorrhiza (M), Biochar+Mycorrhiza (BM), No Treatment (NT). 
A significant difference $(\mathrm{P}=0.0000)$ was observed on the population of arbuscular mycorrhizal fungi (AMF) spores as a result of different soil amendments. The highest number of AMF was isolated from the plot amended with vermicompost (V), with 1,348 isolates, followed by biochar (B) with 1,325 isolates, and the MV block with 1,242 in that decreasing order (Figure 1).

Glomus etunicatum, was the most frequently isolated species with a mean of 117 , followed by Glomus intraradices at 79.6, Glomus mosseae with 61.7 in that decreasing order. The least frequently occurring species was Gigaspora albida with a mean of 3.04. The most frequently occurring genus was Scutellospora, with 4 species, while the least frequently occurring genus was Gigaspora (Table 5).

Table 5. Diversity of arbuscular mycorrhizal fungi isolated after the study.

\begin{tabular}{lllllll}
\hline Isolate & Rank & $\begin{array}{l}\text { No. of } \\
\text { isolates }\end{array}$ & Mean & Proportion & $\begin{array}{l}\text { Cum } \\
\text { frequency }\end{array}$ & $\begin{array}{l}\text { P value } \\
(\mathbf{P}=\mathbf{0 . 0 5})\end{array}$ \\
\hline $\begin{array}{llllll}\text { G. etunicatum } \\
\text { G. intraradices }\end{array}$ & 1 & 2797 & 117 & 33.7 & 33.7 & 0.307 \\
G. mosseae & 3 & 1910 & 79.6 & 23 & 56.7 & 0.018 \\
A. denticulata & 4 & 7481 & 61.7 & 17.8 & 74.6 & 0.073 \\
S. nigra & 5 & 605 & 25.2 & 7.3 & 91.1 & 0.032 \\
S. verrucosa & 6 & 409 & 17 & 4.9 & 96 & 0.197 \\
S. calospora & 7 & 166 & 6.92 & 2 & 98 & 0.563 \\
S. pellusida & 8 & 90 & 3.75 & 1.1 & 99.1 & 0.06 \\
$\begin{array}{l}\text { Gigaspora } \\
\text { albida }\end{array}$ & 9 & 73 & 3.04 & 0.9 & 100 & 0.026 \\
\hline
\end{tabular}

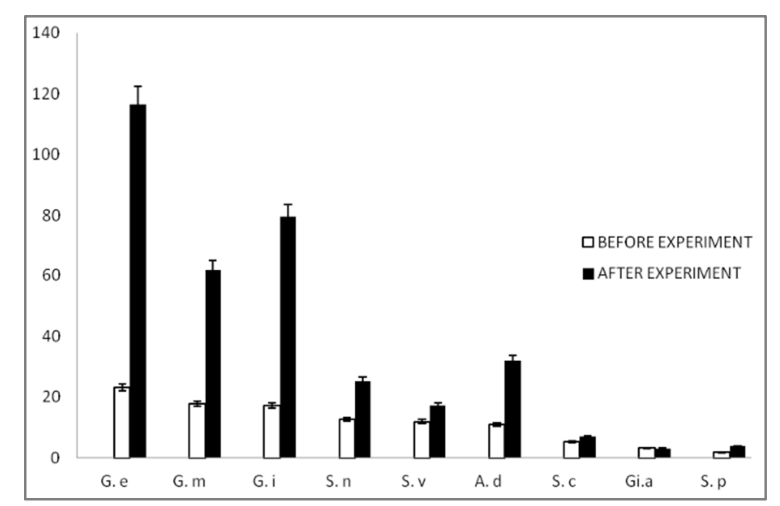

Figure 2. Comparison of mean occurrence of Arbuscular Mycorrhizal Fungi before and after the experiment.

Key: G. e: Glomus etunicatum, G. m: Glomus mosseae, G. i: Glomus intraradices, S. n: Scutellospora nigra, S. v: Scutellospora verrucosa, A. d: Acaulospora denticulata, S. c: Scutellospora calospora, Gi. a: Gigaspora albida, S. p: Scutellospora pellusida.

Glomus etunicatum was ranked first in frequency of occurrence both before and after application of amendments. The population of Glomus intraradices surpassed that of Glomus mosseae, which ranked second as the most frequently occurring isolate before the experiment. Acaulospora denticulata also occurred more frequently than Scutellospora nigra at the end of the experiment. The population of Scutellospora pellusida was also higher than that of Gigaspora albida at the end of the experiment (Figure 2).

\subsection{Effects of Soil Amendments on Root Colonisation}

No significant difference $(\mathrm{P}=0.926)$ was observed on both the frequency $(\mathrm{F} \%)$ and intensity $(\mathrm{M} \%)$ of mycorrhiza in the root system as a result of applying different soil amendments on different plots. However, all treatments had significantly $(\mathrm{P}<0.05)$ higher levels of colonization than those of the control. A significant difference $(\mathrm{P}<0.05)$ was observed on the percentage of arbuscules in the root system as a result of applications of different soil amendments (Table 6).

Table 6. Mean occurrence of mycorrhiza in root system of soybean plants.

\begin{tabular}{llllll}
\hline TREATMENT & $\mathbf{F \%}$ & $\mathbf{M} \%$ & $\mathbf{m \%}$ & $\mathbf{a \%}$ & $\mathbf{A \%}$ \\
\hline MV & $92.2 \mathrm{a}$ & $22.7 \mathrm{a}$ & $24.6 \mathrm{ab}$ & $42.0 \mathrm{ab}$ & $9.5 \mathrm{ab}$ \\
B & $88.9 \mathrm{a}$ & $23.4 \mathrm{a}$ & $27.4 \mathrm{ab}$ & $50.4 \mathrm{a}$ & $11.9 \mathrm{ab}$ \\
BVM & $86.7 \mathrm{a}$ & $22.6 \mathrm{a}$ & $26.0 \mathrm{ab}$ & $43.6 \mathrm{ab}$ & $10.2 \mathrm{ab}$ \\
BV & $83.3 \mathrm{a}$ & $25.3 \mathrm{a}$ & $30.2 \mathrm{a}$ & $56.0 \mathrm{a}$ & $14.7 \mathrm{ab}$ \\
V & $80.0 \mathrm{a}$ & $23.7 \mathrm{a}$ & $29.1 \mathrm{a}$ & $54.4 \mathrm{a}$ & $14.2 \mathrm{a}$ \\
BM & $76.7 \mathrm{a}$ & $21.8 \mathrm{a}$ & $28.6 \mathrm{a}$ & $55.6 \mathrm{a}$ & $12.0 \mathrm{ab}$ \\
M & $75.6 \mathrm{a}$ & $21.3 \mathrm{a}$ & $27.2 \mathrm{ab}$ & $52.8 \mathrm{a}$ & $14.0 \mathrm{a}$ \\
NT & $56.7 \mathrm{~b}$ & $5.8 \mathrm{~b}$ & $11.0 \mathrm{~b}$ & $20.5 \mathrm{~b}$ & $1.2 \mathrm{~b}$ \\
Mean & 80 & 20.8 & 25.5 & 46.9 & 10.5 \\
LSD (0.05) & 17.3 & 15.1 & 17.2 & 29.4 & 12.3 \\
cV $(\%)$ & 12.4 & 41.3 & 38.5 & 35.8 & 66.7 \\
\hline
\end{tabular}

Key: F\%- Frequency of mycorrhiza in root system, M\%- Intensity of mycorrhizal colonisation in root system, $\mathrm{m} \%$ - Intensity of mycorrhizal colonisation in root fragments, $\mathrm{a} \%$ - Arbuscule abundance in mycorrhizal parts of root fragments, A\%- Arbuscule abundance in root system. Treatments with different letters are significantly different.

\subsection{Effect of Soil Amendments on Soybean Plants and Harvest}

At harvest time, the biochar block recorded the highest percentage change in shoot weight, at $235.29 \%$ up from the weight taken at flowering time, followed by the BM block and the $\mathrm{M}$ block, in that decreasing order. The highest percentage change in root weight was recorded in the vermicompost block, followed by the BM block and the $\mathrm{M}$ blocks in that decreasing order (Table 7).

Table 7. Percentage change in shoot and root weight of soybean plants at the end of the study

\begin{tabular}{|c|c|c|c|c|c|c|}
\hline Treatment & Shoot weight & & & Root weight & & \\
\hline t & Flowering (kg) & Harvest (kg) & \%change & Flowering (g) & Harvest (g) & \%change \\
\hline MV & 0.49 & 0.76 & 55.1 & 70.1 & 74.2 & 5.85 \\
\hline BM & 0.38 & 1 & 163.16 & 51.71 & 73.5 & 42.14 \\
\hline V & 0.4 & 0.95 & 137.5 & 51.04 & 88.7 & 73.79 \\
\hline B & 0.34 & 1.14 & 235.29 & 78.6 & 86.23 & 9.71 \\
\hline NT & 0.56 & 0.87 & 55.36 & 70.05 & 77.07 & 10.02 \\
\hline M & 0.52 & 1.12 & 115.38 & 51.39 & 70.4 & 36.99 \\
\hline BVM & 0.46 & 0.7 & 52.17 & 71.75 & 78.53 & 9.45 \\
\hline BV & 0.52 & 0.75 & 44.23 & 77.36 & 66 & -14.68 \\
\hline
\end{tabular}


At harvest, the B blocks recorded the heaviest weight of soybean seeds, at a mean of $171.28 \mathrm{~g}$, followed by the $\mathrm{V}$ blocks and the BVM blocks, as shown in figure 3. Compared to the other treatment blocks, the blocks treated with mycorrhiza had the lowest harvest weight of soybean seeds at $58.17 \mathrm{~g}$ (Figure 3).

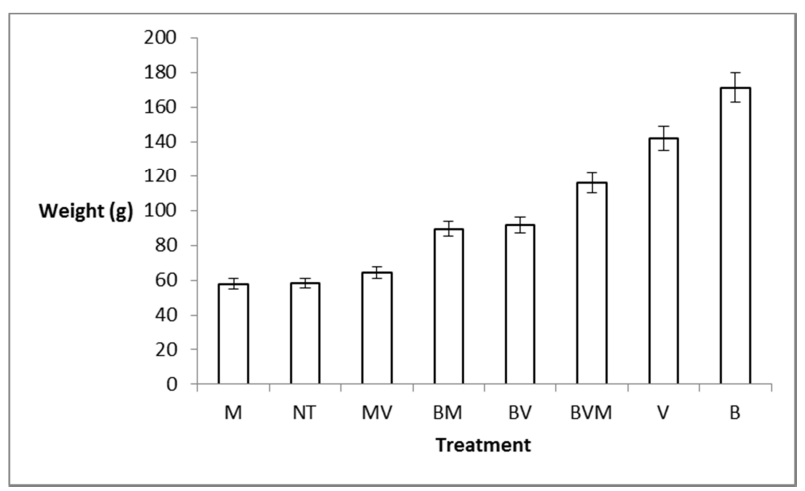

Figure 3. Weight of soybean seeds across treatments at harvest time.

\section{Discussion}

Phosphorous content in the soil increased after application of soil amendments. Blocks that were treated with vermicompost registered high levels of phosphorous. This could be due to the fact that the vermicompost used as an amendment had high levels of phosphorous. [15] reported that application of vermicompost increased the N, P and $\mathrm{K}$ content of the soil. The results in this study also concur with [16], who found that application of biochar and AM fungi significantly increased total soil P content. They suggested that the increase in phosphorous was related to the supply of high surface area provided by biochar which created a better habitat for the development and activities of soil microorganisms, which in turn increased the availability of soil phosphorous.

Blocks treated with the biochar recorded higher levels of $\mathrm{pH}$ than the control block. This could be attributed to the high initial $\mathrm{pH}$ recorded on the biochar that was used in the study. These results agree with [17] who found that application of biochar as a soil amendment increased soil $\mathrm{pH}$. Blocks treated with vermicompost and mycorrhiza recorded $\mathrm{pH}$ lower than the initial $\mathrm{pH}$. It could be that addition of the amendments produced a favourable environment for development of micro-organisms, whose metabolic processes resulted in an increase in acidity in the soil. These results agree with [15] who also reported a reduction in soil $\mathrm{pH}$ after application of vermicompost and mycorrhiza to soils in orchards.

The nitrogen content across all treatments generally reduced. According to [18], biochar has been known to decrease $\mathrm{N}$ availability. [19] reported a reduction in soil $\mathrm{N}$ after application of biochar.[20] proposed that biochar may in the short term reduce ammonification either in $\mathrm{N}$ availability due to immobilization during initial decomposition of the Npoor biochar or by a reduction in carbon cycling.
Carbon content in the soil increased as a result of application of amendments. This could be due to the fact that the amendments provided a suitable environment for dvelopment of micro-organisms, whose metabolic activities led to an increase in carbon. [15] reported an increase in soil carbon content after application of vermicompost. In another study, application of biochar to soils led to an increase in soil organic carbon, among other nutrients [17].

The addition of organic amendments to the soil enhanced sporulation. Moreover, the addition of commercial strains of mycorrhiza did not result in an increase in sporulation. The amendments may have enhanced development of both indigenous and introduced mycorrhizal fungi while the commercial strains introduced in some of the blocks may have taken time to adjust to the environment. These results agree with [16] who found that a block treated with biochar alone recorded the highest abundance of spores, compared to blocks treated with a combination of biochar and mycorrhiza, and attributed this to the slow adjustment of the introduced mycorrhizal species to the environment. The results of this study also agree with [21], who found that substrates treated with vermicompost produced the highest number of mycorrhizal spoeres compared with substrates treated with coir dust and Topstrato ${ }^{\mathrm{TM}}$. They attributed this to the high levels of phosphorous in the substrate provided by vermicompost, which played an improtant role in production of AM fungi propagules.

In terms of diversity, the genus Glomus recorded the highest spore count while Gigaspora recorded the lowest. It should be noted that the commercial mycorrhiza added to some of the plots contained Glomus spp. This, coupled with the presence of Glomus species in the soil before addition of the amendments, could explain the high spore count recorded. These results are consistent with a study carried out by [22] on the occurrence of AM fungi after organic fertilization, who found that Glomus species had the highest presence, presumably because species in this genus generally predominate in a $\mathrm{pH}$ of 6.0 to 8.0 . The soil $\mathrm{pH}$ during this experiment ranged from 7.0 to 7.41 . In addition, Glomus has the capacity to adapt to different organic matter contents in the soil. Furthermore, genera such as Glomus and Acaulospora produce small spores and are able to survive by adapting their sporulation patterns under unfavourable conditions like aridity [22]. The results of this study also agree with [21], who found that members of the Gigasporaceae family generally produce few spores and are incapable of colonising from hyphal fragments.

In this study, the population of Acaulospora spp exceeded that of the initial population of Scutellospora spp. It seems that some species respond better to organic fertilisation than other species. These results concur with [23], who reported a high frequency of occurence of Acaulospora species and a low frequency of occurence of Gigaspora and Scutellospora in areas owith organic fertilisation.

Contrary to the reuslts of this study, [14] found that spore densities in the soil were not affected by addition of 
phosphorous. [22], reported negative responses of AM fungi due to the incorporation of organic residues to high nutrient content of these materials, presence of phytotoxic substances, specific composition of the residue and pressure of pathogens.

All the blocks treated with soil amendments resulted in significantly $(\mathrm{P}=0.0000)$ higher root colonisation than the control block. The B and BM blocks came fourth and fifth respectively, while the BVM block had the second lowest root colonisation rates. This indicates that the soil amendments enhanced the activities of the already-present mycorrhiza species in the soil without requiring the addition of commercial mycorrhiza. The results from this study show that the net effect of biochar on root colonisation was negative. These results agree with [20] who reported that application of biochar at different rates resulted in neutral to decreased AM fungi abundance, which was measured by percent root colonisation and/ or extraradical hyphae production. The study suggested that biochar's capacity to adsorb signaling compounds and act as a sink could decrease ability of mycorrhizal fungi to colonise plant roots. Permanent removal of signal molecules from soils could result in a net decrease in the number of signal molecules reaching mycorrhizal hyphae and spores, leading to a decrease in hyphal growth and spore germination and ultimately, fungal abundance. In addition, Biochar could also adsorb compounds toxic to mycorrhizal fungi [20]. However, contrary to the results in this study, positive effects on AM fungi root colonisation as a result of application of biochar to soil have been reported. [24] Found that AM fungi colonisation increased significantly in the biochar treatment for wheat grown in well-watered and periodic water stressed environments.

The results of this study show that the net effect of vermicompost on colonisation of soybean roots by mycorrhiza was positive. This result is consistent with previous findings by [22], who suggested that transport and absorption in mycelia of AM Fungi were favoured by humic substances like fulvic acids that result from the decomposition of organic fertilisers. The results of this study differ with [25] who found that mycorrhizal colonisation and arbuscule formation significantly decreased with the increase of green compost in soil. [21] Suggested that some substances present in organic composts could have a phytotoxic effect and/ or inhibit the development of AM fungi.

The highest soybean harvest was recorded in the biochar and vermicompost treatment plots respectively. This indicated that in addition to enhancing colonisation of soybean roots by mycorrhiza, soil amendments also enhanced plant growth and yield. These results agree with a study where application of biochar increased yield of maize over the control plot by 2.2 tonnes per hectare [17].[26] also reported that biological yield was greater when vermicompost was applied along with azotobacter and arbuscular fungi, while according to [25], the best dry weight yield occurred at compost rates of $75 \%$ and AM fungi application. Contrary to the results in this study, [27] suggested that while vermicompost stimulated fungal development, as much as $20 \%$ of the total carbon assimilated by the sorghum plants may have been taken up by the mycorrhizal fungi. They concluded that the effect of vermicompost on mycorrhizal colonization was harmful, rather than beneficial, to plant growth. Contrary to the results in this study, [20] reported that plant biomass production was not significantly affected by addition of biochar. The mycorrhiza block recorded the lowest harvest of soybean seeds compared to the blocks treated with biochar and / or vermicompost. This could mean that these amendments enhanced the activities of the beneficial microorganisms in the soil, including indigenous mycorrhiza, by improving the soil properties, and creating a conducive environment for their development, thus leading to higher yields. In their study, [25] found that the best dry weight yield occurred at compost rates of $75 \%$ and AM fungi application.

\section{Conclusion}

The study has established the presence of indigenous populations of arbuscular mycorrhizal fungi in the Sulmac area of Naivasha. The study also showed that application of amendments to soil enhances colonisation of soybean roots by arbuscular mycorrhizal fungi. Plots that were treated with biochar and vermicompost showed greater colonisation than plots treated only with mycorrhiza. This showed that the amendments enhanced the activities of AM fungi that are indigenous to the soil without the need to apply additional commercial strains. The highest yield of soybean was in the plots treated with biochar and vermicompost respectively, again showing that these amendments both encouraged plant growth through improvement of soil characteristics and enhancement of the action of indigenous mycorrhiza.

It is evident that organic amendments and biochar have a positive impact on soil microbial organisms. They can improve the soil environment to aid the action of indigenous organisms, and also have a positive impact on general plant health through provision of additional nutrients and improving the soil structure, which in turn leads to increased plant growth and yield, without the negative effects on the environment brought about by inorganic fertilisers.

\section{Recommendation}

Further studies should be carried out to establish the effect of these soil amendments on individual species of arbuscular mycorrhizal fungi.

\section{Acknowledgements}

The authors would like to acknowledge the following institutions for facilitating this study: Dudutech Ltd., Kenya Agricultural Research Institute (KARI), Kenya Forestry Research Institute (KEFRI) and the University of Nairobi. 


\section{References}

[1] Adewole, M. B., Awotoye, O. O., Ohiembor, M. O. \& Salami, A. O. (2010). Influence of mycorrhizal fungi on phytoremediating potential and yield of sunflower in $\mathrm{Cd}$ and $\mathrm{Pb}$ polluted soils. Journal of Agricultural Sciences, 55 (1), 17-28.

[2] Brundrett, M. (2009). Mycorrhizas in Natural Ecosystems. Advances In Ecological Research, 21, 171-313.

[3] Nepolean, P., Jayanthi, R., Vidhya Palavi, R., Balamurugan, A., Kuberan, T., Beulah, T., \& Premkumar, R. (2012). Role of Biofertilisers in Increasing Tea Productivity. Asian Pacific Journal of Tropical Biomedicine, S 1443-S 1445.

[4] Douds Jr., D. D, Lee, J., Uknalis, J., Boateng, A. A. \& ZieglerUlsh, C., (2014). Pelletized biochar as a carrier for AM fungi in the on-farm system of inoculum production in compost and vermiculite mixtures. Compost Science \& Utilization, 22 (4), 253-262.

[5] Bakry Ahmed Bakry, Omar Maghawry Ibrahim, Abdelraouf Ramadan Eid \& Elham Abdelmoneim Badr. (2014). Effect of humic acid, mycorrhiza inoculation, and biochar on yield and water use efficiency of flax under newly reclaimed sandy soil. Agricultural Sciences, 5, 1427-1432.

[6] Verheijen, F. G., Jeffery, S., Bastos, A. C., van der Velde, M., \& Diafas, I. (2010). Biochar Application to Soils - A Critical Scientific Review of Effects on Soil Properties, Processes and Functions (No. EUR 24099 EN) (pp. 1-149). Luxembourg: Office for the Official Publications of the European Communities.

[7] Schahczenski, J. (2010). Biochar and Sustainable Agriculture. National Sustsainable Agriculture Information Service. Retrieved from www.attra.ncat.org/attrapub/PDF/biochar.pdf.

[8] Lazcano, C., Arnold, J., Tato, A., Zaller, J. G., \& Domínguez, J. (2009). Compost and vermicompost as nursery pot components: effects on tomato plant growth and morphology. Spanish Journal of Agricultural Research. 7 (4), 944-951.

[9] Sinha, R. K. (2009). Earthworms vermicompost: a powerful crop nutrient over the conventional compost \& protective soil conditioner against the destructive chemical fertilisers for food safety and security. American-Eurasian Journal of Agricultural and Environmental Sciences, 5 (S), 1-55.

[10] Darzi, M. T., Seyedhadi, M. H., Rejali, F. (2012). Effects of the application of vermicompost and phosphate solubilizing bacterium on the morphological traits and seed yield of anise (Pimpinella anisum L.) Journal of Medicinal Plants Research, $6(2), 215-219$.

[11] Girma, A., Rossiter, D., Siderius, W., \& Henneman, I. (2001). Soils of the Lake Naivasha Area, Kenya (Technical Report) (pp. 1-34). the Netherlands: International Institute for Aerospace Survey \& Earth Sciences.

[12] Muchane, M. N., Muchane, M., Mugoya, C., \& Masiga, C. (2012). Effect of land use system on Arbuscular Mycorrhiza fungi in Maasai Mara ecosystem, Kenya. African Journal of Microbiology Research, 6 (17), 3904-3916.

[13] Machua, J. M. (2002). Mycorrhiza Staining Methods. Kenya Forest Research Institute.

[14] Mathimaran, N., Ruh, R., Jama, B., Verchot, L., Frossard, E., \& Jansa, J. (2007). Impact of agricultural management on arbuscular mycorrhizal fungal communities in Kenyan ferralsol. Agriculture, Ecosystems and Environment, 119, 22-32.

[15] Jain, M. C., Sharma, M. K., Bhatnagar, P., Meena, M., \& Yadav, R. K. (2012). Effect of Mycorrhiza and Vermicompost on Properties of Vertisol Soil and Leaf Content of Nagpur Mandarin (Citrus reticulata Blanco). Asian Journal of Horticulture, 7 (2), 528-532.

[16] Mau, A. E., \& Utami, S. R. (2014). Effects of Biochar amendment and arbuscular mycorrhizal fungi inoculation on availability of soil phosphorous and growth of maize. Journal Of Degraded And Mining Lands Management, 1 (2), 69-74.

[17] Laufer, J., \& Tomlinson, T. (2013) Biochar Field Studies: An IBI Research Summary (Research Summary) (pp. 1-10). International Biochar Initative.

[18] Lehmann, J., Rillig, M. C., Thies, J., Masiello, C. A., Hockaday, W. C., \& Crowley, D. (2011). Biochar effects on soil biota - A review. Soil Biology \& Biochemistry, 43, 1812-1836.

[19] Elmer, W. H., \& Pignatello, J. J. (2011). Effect of Biochar Amendments on Mycorrhizal Associations and Fusarium Crown and Root Rot of Asparagus in Replant Soils. Plant Disease, 95 (8), 960-966.

[20] Warnock, D., Mummey, D., McBride, B., Major, J., Lehmann, J., \& Rillig, M. (2010). Influences of non-herbaceous biochar on arbuscular mycorrhizal fungal abundances in roots and soils: Results from growth-chamber and field experiments. Applied Soil Ecology, 46, 450-456.

[21] Coelho, I., Pedone-Bonfim, M., Silva, F., \& Maia, L. (2014). Optimization of the production of mycorrhizal inoculum on substrate with organic fertilizer. Brazilian Journal of Microbiology, 45 (4), 1173-1178.

[22] Sousa, C. da S., Menezes, R. S. C., Sampaio, E. V. de S., Oehl, F., Maia, L. C., Garrido, M. da S., \& Lima, F. de S. (2012). Occurrence of arbuscular mycorrhizal fungi after organic fertilization in maize, cowpea and cotton intercropping systems. Acta Scientarum, 34 (2), 149-156.

[23] Oehl, F., Sieverding, E., Ineichen, K., Mader, P., Boller, T., \& Wiemken, A. (2003). Impact of Land Use Intensity on the Species Diversity of Arbuscular Mycorrhizal Fungi in Agroecosystems of Central Europe. Applied And Environmental Microbiology, 69 (5), 2816-2824.

[24] Solaiman, Z., Sarcheshmehpour, M., Abbott, L., \& Blackwell, P. (2010). Effect of biochar on arbuscular mycorrhizal colonisation, growth, P nutrition and leaf gas exchange of wheat and clover influenced by different water regimes. In Soil Solutions for a Changing World. Brisbane, Australia: 19th World Congress of Soil Science.

[25] Copetta, A., Bardi, L., Bertolone, E., \& Berta, G. (2011). Fruit production and quality of tomato plants (Solanum lycopersicum L.) are affected by green compost and arbuscular mycorrhizal fungi. Plant Biosystems, 145 (1), 106-115.

[26] Shishehbor, M., Madani, H., \& Ardakani, M. (2013). Effect of vermicompost and Biofertilizers on yield and yield components of common millet (Panicum miliaceum). Annals of Biological Research, 4 (2), 174-180.

[27] Cavender, N., Atiyeh, R., \& Knee, M. (2003). Vermicompost stimulates mycorrhizal colonization of roots ol Sorghum hicolor at the expense of plant growth. Pedobiologia, 47, 8589. 